Monika Smyth

(D) https://orcid.org/0000-0002-9468-0136

The Pontifical University of John Paul II in Krakow

\title{
Book review: Adrian Tinniswood, Brytyjska monarchia od kuchni [Behind the Throne: A Domestic History of the British Royal Household], publ. Bellona, Warszawa 2019, pp. 527
}

Adrian Tinniswood, both a careful scholar and a nimble writer, lecturer at the University of Oxford and the University of California, Berkeley in one of his newest books Behind the Throne: A Domestic History of the British Royal Household creates a story about life behind the door of the royal palaces in Britain. It combines the relations between the royal family and its household, showing not only the difference between them, but also their interdependence. The whole is compressed into a little over 500 pages and closed into 12 chapters.

As the author states himself his book is not about the business of ruling. Instead Tinniswood concentrates on the private lives of royalty, from Elizabeth I to Elizabeth II and focuses on a meticulous analysis of how the business of looking after royalty has changed, or remained the same, over the past five centuries.

The reader hopes to receive an interesting study of the subject based on original sources and carefully selected literature on the subject. And the reviewed work, which contains many quotes from original sources, meets these expectations fully. The great advantage of this monumental work is its vivid, colorful language, devoid of artificiality, and at times funny.

As indicated in the introduction the elements are presented in chronological order. In the first chapter Progress, the author presents the first queen 
Elizabeth and her court, dazzling and displaying its splendor during the queen's annual trips around the country. As Elizabeth showed cumbersome willingness to travel in the company of her huge retinue (consisting of the Privy Council, numerous courtiers and servants) she had to be aware that uncontrolled costs meant trouble with Parliament.

In the next chapter Behind the Masque, Tinniswood reveals financial careless of James I, who often got involved in costly ventures, spending vast sums of money on his favorite masquerades and a new banqueting hall at Whitehall. While in the chapter Diplomats and Fools, he concentrates on the activities of diplomatic services and the responsibilities of the newly-created office - Master of Ceremonies. Furthermore he describes misfits, or fools, individuals who have seemingly failed to hold their ground as royal servants.

Tinniswod recalls two stories in the chapter A Court Without a King one of Lord Protector Oliver Cromwell, who was a king in death, if not in life. At his funeral his image, dressed in royal robes, with a scepter and a globe in both hands and a crown on his head was mounted on a chariot. And another one of the royal possessions (goods and personal estates of the late king) arranged by the Parliament's act for sale, which was the greatest sale of art objects in England's history.

Two following chapters We Have Called You Gods and The Catholic King the author continues his tale of the Stuarts. Charles II, called back from exile in 1660, promised to put an end to the excesses known to be in great offices. However, the attraction of glamor and glory was too much and soon he irritated the public with his generous expenditures. Charles II's heir, and younger brother, James II, known as "Dismal Jimmy," and Catholic convert, tried to modernize English royal court. Suspected by his subjects of an attempt to restore Catholicism in England he was best remembered for his life motto "don't ask, don't tell and the Glorious Revolution, that saw him deposed in favour of William of Orange and his older daughter, Mary II.

After Mary and William died without an issue, the crown went to Anne, James II's younger daughter. She developed an extraordinarily close relationship with Sarah, Duchess of Marlborough, who held a significant role in her royal household. Both women adopted personae "Mrs. Morley and Mrs. Freeman," to feel less bounded by the royal protocol. As the balance of power within the relationship was wrong, Sarah exploited this one-sided relationship to her own ends.

In the chapter Happy Families Tinniswood carefully recreates the realities of the court of the first Hanoverian kings, who lived mostly outside 
London, in a somewhat bourgeois atmosphere, where the main extravagance was music as George I brought with him George Frideric Händel. He does not remain silent about the family conflicts which divided not only the family but also formed separate court parties, politically supported by the political groups of the Whigs and Tories.

The next chapter An Agitation of Spirits is dedicated to the king George III's madness, of which a reader is spared no detail (vulgarity and sexual hyperactivity is all there). As well as sometimes shocking medical treatments (which today would be considered a significant abuse) of the royal patient by a team of professionals, lead by mad Dr. Willis.

Further chapter Regent focuses on George, Prince of Wales, who became the Prince Regent in 1811 following yet another attack of King George III's madness. The prince was known for his boisterous and scandalous lifestyle and surrounding himself with a court of exactly same manners.

In next two chapters The Respectable Household and After Albert Tinniswood discusses Queen Victoria and Prince Albert's lives and their royal court. Under Victoria, some kind of modernization of the royal court began: a few senior servicemen became private secretaries and assistants to private secretaries, and their successors were often family members. The royal household expanded, nine royal children needed carers, kindergarten staff, tutors and educators. Victoria and Albert realized the importance of keeping spending under control. Thus, the prerogatives of some officials changed, and the courtiers began to notice the need to adapt the monarchy and the court to new times and the ways of democracy.

In the beginning of the 2oth century the monarchy, principally during the reign of Edward VII, became progressively dependent on exhibitions and ceremonies, importance and attractiveness. So in the chapter Court Circular Tinniswood describes the army of staff and functionaries that became essential to maintain the show. He continues with that description in the next two chapters That Dear Little Man and Secretaries concentrating on the rise of the private secretary, who became the most important office holder at court of George V and his son, Edward VIII.

In one of the closing chapters Gloriana the author gives his readers glimpses into the preparations for the coronation of Queen Elizabeth II a ceremony which was, as he states "the last great public gathering of the royal household in the twentieth century." Because it was broadcasted by the BBC all over the word it "was seen by more people than all the other British coronations in history put together." 
The final chapter Affective Memories focuses on the royal code of secrecy and royal servants selling their stories to the press. From Marion Crawford (Crawfie), governess to the Queen and Princess Margaret who published her book Little Princesses in 1949, to the memoirs of Paul Burrell, butler of the late Diana, Princess of Wales, the lives of members of the British royal family become a lucrative livelihood for former royal servants.

"It's all to do with the training - as a postscript, the author presents a description of the contemporary situation of the royal family and a royal household, which after the death of Princess Diana underwent a metamorphosis. Currently, it is a thriving modern corporation, called by some a firm, present in social media, deriving tangible financial benefits from its popularity. However, still attached to its unique status and old traditions.

Behind the Throne... is a wonderfully entertaining account of life through five centuries of royal households, full of anecdotes told in a colorful language. Thanks to this, the book meets expectations not only of professional historians, but also everyone interested in the history of the British royal family. 